\author{
Monika Bojanowska, MaŁgorzata KosteckA
}

\author{
Katedra Chemii \\ Wydział Nauk o Żywności i Biotechnologii \\ Uniwersytet Przyrodniczy $w$ Lublinie \\ Skromna 8, 20-704 Lublin \\ E-mail: monika.bojanowska@up.lublin.pl
}

\title{
DIETA I STYL ŻYCIA JAKO CZYNNIKI WPŁYWAJĄCE NA PŁODNOŚĆ
}

\section{WSTEP}

W dzisiejszym świecie coraz bardziej powszechne staje się zjawisko niepłodności. W Polsce, jak podaje Polskie Towarzystwo Ginekologiczne, problem ten dotyka już 1,5 mln par, a biorac pod uwagę zachodzące zmiany demograficzne, należy założyć, że zjawisko to będzie się nasilać. Światowa Organizacja Zdrowia (WHO) uznała ja jako chorobę cywilizacyjna i usytuowała w Międzynarodowej Klasyfikacji Chorób i Problemów Zdrowotnych, a kurację zaburzeń płodności zakwalifikowała do podstawowych praw człowieka. Według szacunkowych statystyk swiatowych problem niepłodności dotyczy 10-18\% populacji na świecie (RAPORT 2015), a w krajach afrykańskich i Ameryki Południowej nawet przewyższa ten poziom. Do najczęstszych przyczyn tego zjawiska należa zaburzenia owulacji u kobiet, natomiast w przypadku mężczyzn, sa to nieprawidłowe parametry nasienia i zaburzenia hormonalne (COHEN 2011, JEZNACH-STEINHAGEN i CZERWONOGRODZKA-SENCZYNA 2013). Jednak coraz powszechniej za podłoże zaburzeń płodności uznaje się nieracjonalna dietę i niewłaściwy styl życia, a zwłaszcza spożywanie wysoko przetworzonej żywności, ubogiej w witaminy i minerały, jak również niewystarczający poziom aktywności fizycznej oraz częste sięganie po używki takie jak: alkohol, papierosy czy kawa (ŚwiĄTKOWSKA 2013). Obecnie w Polsce problem niepłodności dotyczy 13-15\% par starajacych się o potomstwo. Ze statystyk wynika, iż w 35\% przyczyna zaburzeń płodności leży po stronie kobiety i w takim samym stopniu po stronie mężczyzny. Nato- miast w $10 \%$ problem tkwi po obydwu stronach, a w pozostałych $20 \%$ powód występujaccej niepłodności nie jest ustalony (BOIVINI i współaut. 2007). Najlepszym sposobem ograniczenia występowania różnych chorób nie jest ich leczenie, ale zapobieganie. Istnieja dowody, że pewne aspekty stylu życia (sposób żywienia, palenie papierosów, spożycie alkoholu i aktywność fizyczna) moga mieć negatywny wpływ na ogólny stan zdrowia, w tym także zdolności reprodukcyjne (HoMAN i współaut. 2007). Istnieje wiele chorób, zwanych dietozależnymi, które w dużej mierze wynikaja $z$ nieracjonalnego i niezbilansowanego sposobu żywienia lub niewłaściwej jakości zdrowotnej żywności (RoszKowsKI i RoszKowsKA 2009). Również w przypadku płodności przywiązuje się większą uwagę do roli składników żywności, ich wpływu na proces jej potęgowania, bądź hamowania (HAJDUK 2013). Dlatego té̇ coraz częściej przeprowadzane sa badania w tym kierunku. Wyniki Nurses Health Study II (NHS II), trwajacego 8 lat i obejmujacego 17,5 tys. kobiet w wieku 25-42 lat w okresie prokreacyjnym udowodniły, iż pewne aspekty $\dot{z} y-$ wieniowe moga skutkować spadkiem ryzyka niepłodności, spowodowanej nieprawidłowymi owulacjami. Składniki pokarmowe zawarte w żywności w znacznym stopniu wpływają na poziom hormonów w organizmie człowieka, a zwłaszcza insuliny. Jest to istotne, gdyż insulinooporność ściśle koreluje $z$ procesem owulacji i płodnością (CHAVARRO i współaut. 2009). Zdolność poczęcia dziecka w przypadku mężczyzn jest uzależniona przede wszystkim od jakości i ilości nasienia, a także poziomu testosteronu. Nieprawidłowe ich pa- 
rametry należą do najczęstszych przyczyn zaburzeń męskiej płodności, a odpowiednio zrównoważona dieta może przyczyniać się do znacznej poprawy tych wskaźników (SzOSTAK-WĘGIEREK 2011, HOSSEINI i ESLAMIAN 2014).

\section{MAKROSKŁADNIKI}

Pierwszą, istotną składową modelu żywienia sprzyjającego płodności sa tłuszcze roślinne. Ważne jest, aby dieta była przede wszystkim bogata w jedno- $i$ wielonienasycone kwasy tłuszczowe. Można je dostarczyć poprzez spożycie oliwy $z$ oliwek, oleju rzepakowego, a także miękkich margaryn. Równolegle, zasadniczym elementem jest ograniczenie tłuszczów nasyconych i rezygnacja $z$ izomerów trans nienasyconych kwasów tłuszczowych (TFA) (CHAVARRO i współaut. 2007c). Głównym źródłem kwasów tłuszczowych nasyconych (SFA) jest tłuste mleko, sery podpuszczkowe, śmietana, olej palmowy czy kokosowy. Zauważono niekorzystny wpływ nasyconych kwasów tłuszczowych na etapy cyklu menstruacyjnego i czas ich trwania (REICHMANN i wpółaut. 1992). Natomiast izomery trans w dużej ilości moga występować w twardych margarynach, czekoladzie, gotowych wyrobach piekarniczych czy fast foodach (PRZYSŁAWSKI i współaut. 2010). Oddziaływanie na organizm TFA było przedmiotem wielu badań, wskazujących jednoznacznie ich negatywny wpływ na funkcje organizmu, t.j. podwyższanie poziomu całkowitego cholesterolu, cholesterolu LDL (ang. low density lipoprotein), a także trójglicerydów oraz spadek poziomu HDL (ang. high density lipoprotein) (SARAVANAN i współaut. 2005, KocHAN i współaut. 2010). Zwiększenie spożycia tłuszczów trans o $2 \%$, kosztem jednoniensyconych kwasów tłuszczowych, powoduje dwukrotne nasilenie się wystapienia problemów $\mathrm{z}$ poczęciem dziecka (CHAVARRo i współaut. 2007c). Może być to skutkiem oddziaływania izomerów trans na funkcjonowanie receptora PPAR- $\gamma$, uczestniczacego w metabolizmie glukozy. Zmniejszenie aktywności tego receptora przez izomery trans prowadzi do zwiększenia oporności na insulinę oraz do nasilenia procesu zapalnego. $Z$ kolei jednonienasycone kwasy tłuszczowe (MUFA) odgrywają ważna rolę w organizmie człowieka, a mianowicie powoduja zwiększenie poziomu tzw. dobrego cholesterolu, HDL. Wyniki badań przeprowadzonych w NHS II udowodniły, iż większe spożycie MUFA w stosunku do podaży trans kwasów tłuszczowych powoduje poprawę rozrodczości, przyczyniając się do polepszenia wrażliwości na insulinę, co pozytywnie koreluje $z$ płodnościa kobiet (CHAVARRO i współ- aut. 2009). Na proces reprodukcji w dużym stopniu wpływa spożycie wielonienasyconych kwasów tłuszczowych omega-3 i omega-6, a zwłaszcza zachowanie właściwej ich proporcji w diecie. W organizmie kwasy te konkuruja o jednakowe enzymy, których zadaniem jest ich przekształcenie do czynnych biologicznie eikozanoidów (MARCINIAK-ŁUKASIAK 2011). Produktami bogatymi w te składniki sa przede wszystkim oleje pochodzenia roślinnego, takie jak rzepakowy, słonecznikowy, krokoszowy czy lniany. Dostarczenie tych składników jest bardzo ważne na każdym etapie życia, a w szczególności podczas ciaży, kiedy po zapłodnieniu ma miejsce rozwój prenatalny. Kwasy omega-3 biora udział w obniżeniu poziomu trójglicerydów, a także w procesie rozwoju mózgu i wzroku. Wpływają również na prawidłowe funkcjonowanie układu krwionośnego oraz zapobiegaja cukrzycy typu II i otyłości. ŁoźNA i współaut. (2012) oraz Missmer i współaut. (2010) opublikowali badania potwierdzajace pozytywny wpływ żywności bogatej w kwasy omega-3 (tuńczyk, łosoś, makrela, olej $z$ orzechów włoskich, olej lniany) na obniżenie prawdopodobieństwa rozwoju endometriozy. Wykazano, że ryzyko endometriozy zmniejszyło się o $70 \%$ w grupie kobiet spożywajacych zielone warzywa, o 40\% wśród kobiet spożywajacych świeże owoce, ale wzrosło dwukrotnie w grupie kobiet, w diecie których znajdowało się dużo wołowiny i innych rodzajów czerwonego mięsa. Na jakość męskiego nasienia pozytywny wpływ wywieraja przede wszystkim kwasy omega-3, a w szczególności kwas a-linolenowy (ATTAMAN i współaut. 2012). U mężczyzn, których dieta była oparta na tych tłuszczach, ilość prawidłowo wykształconych plemników była wyższa, natomiast wzrost ilości izomerów trans kwasów tłuszczowych zmniejszał całkowita liczbę plemników, zarówno u młodych zdrowych mężczyzn (CHAVARRO i współaut. 2014), jak i u mężczyzn niepłodnych (CHAVARRO i współaut. 2011). COMHAIRE (2010) potwierdził, iż podaż kwasu a-linolenowego wraz $z$ dieta wiąże się $z$ odpowiednim skupieniem plemników oraz ich większa aktywnościa, co wpływa na lepsze parametry nasienia. Męskie gonady jąrowe zawierają duże ilości enzymów transformujacych kwas a-linolenowy do kwasu dokozaheksaenowego (DHA), który następnie zostaje wbudowany w błony męskich komórek rozrodczych. Wyniki badań przeprowadzonych na myszach wykazały, iż spożywanie produktów o wysokiej zawartości cholesterolu, może prowadzić do pogorszenia się składu nasienia i aktywności męskich komórek rozrodczych. Może również wpływać na zaburzenie procesu uzdatniania plemników do zapłodnienia (JEZNACH-STEINHAGEN i CZERWO- 
NOGRODZKA-SENCZYNA 2013). Dieta wysokotłuszczowa i bogata w cholesterol może prowadzić do problemów $z$ płodnościa, związanych przede wszystkim $z$ jakościa nasienia u mężczyzn, czy też zaburzeniami owulacji u kobiet (CHAVARRO i wpółaut. 2007b), dlatego w dziennym jadłospisie warto ograniczyć produkty będace ich źródłem.

Kolejnym czynnikiem wpływajacym na rozrodczość jest ilość i jakość węglowodanów dostarczanych organizmowi w pożywieniu. Oddziałuja one znacznie bardziej na stężenie glukozy i insuliny we krwi niż inne elementy pokarmowe. Gdy ich wartość w organizmie jest za duża, zostaje wówczas zaburzona gospodarka hormonów wpływających na płodność, a tym samym następuje zakłócenie owulacji u kobiet. Sekrecja insuliny przez trzustkę oraz insulinopodobnego czynnika wzrostu (IGF-1) powoduje spadek wytwarzania białka SHGB (ang. sex hormone-binding globulin), które wiąże przede wszystkim męskie hormony w krwiobiegu. Prowadzi to do obniżenia ilości białka, przez co we krwi kobiety zaczyna dominować wolny testosteron. Sytuacja ta powoduje zachwianie funkcjonowania hormonów (CHAVARRO i współaut. 2009). Uwarunkowane jest to przede wszystkim dużym spożyciem węglowodanów prostych i produktów wysoko przetworzonych, do których należy m.in. jasne pieczywo, biały ryż, makaron, słodycze, napoje słodzone. Dobrymi zamiennikami tych artykułów będa produkty pełnowartościowe, niskoprzetworzone, $z$ pełnego ziarna i dużą zawartościa błonnika, np. makaron razowy czy brazowy ryż. Warto wybierać produkty o niskim IG i zawierajace błonnik, który w małym tylko stopniu oddziałuje na stężenie glukozy $i$ insuliny w krwiobiegu (CICHON i WĄDOŁOWSKA 2010). Analiza wyników badań wykonanych w Stanach Zjednoczonych wykazała, że u kobiet, które miały większe obciążenie glikemiczne, niepłodność owulacyjna występowała $z$ prawdopodobieństwem wyższym o 92\% niż u kobiet $z$ grupy niskiego obciążenia glikemicznego (CHAVARRO i współaut. 2009). Dieta powinna być także urozmaicona sporą ilością warzyw i owoców (PRZYSŁAWSKI i współaut. 2010). Podobnie jak weglowodany, również rodzaj spożywanego białka może wpływać na stężenie insuliny i glukozy we krwi oraz na wartość czynnika wzrostu IGF1 (Holmes i współaut. 2002). Badania wykonane przez Harvard School of Public Health dotyczace spożycia białka oraz jego wpływu na zaburzenia rozrodczości u kobiet $z$ powodu zaburzeń owulacji wykazały, że podaż większej ilości białka zwierzęcego niż roślinnego powodowała wzrost prawdopodobieństwa wystapienia niepłodności. CHAVARRO i współaut. (2008a) w swoich badaniach udo- wodnili, że dodatek porcji mięsa czerwonego bądź drobiowego do codziennego posiłku, powodował zwiększenie ryzyka zaburzeń rozrodczości nawet o 32\%. Natomiast wzbogacenie dziennej racji pokarmowej dawka warzyw wysokobiałkowych, np. fasoli czy orzechów, wiązało się $z$ obniżeniem ryzyka niepłodności. Ponadto, badania te wykazały, że zamiana 5\% wartości energetycznej $z$ produktów węglowodanowych na białko zwierzęce spowodowała wzrost wystapienia ryzyka nieprawidłowej owulacji aż o 19\%, natomiast wprowadzenie białek roślinnych wiąało się ze spadkiem tego ryzyka nawet o $43 \%$. Jednak najlepszym sposobem na zmniejszenie problemu niepłodności (nawet o 50\%) była zamiana w diecie białek pochodzenia zwierzęcego, na te roślinne. Prawdopodobnie białka te pozytywnie oddziałuja na insulinooporność i zmniejszenie poziomu IGF-1, polipeptydu, który ściśle koreluje $z$ wystąpieniem zaburzeń owulacji u kobiet (HOLMES i współaut. 2002). W innych badaniach, również przeprowadzonych przez CHAVARRO i współaut. (2008c), wysoki poziom tego czynnika powodował zaburzenia owulacji i utrudniał prawidłowy rozwój pęcherzyków jajnikowych na skutek zbyt dużej syntezy androgenów, co prowadziło także do wysokiego poziomu testosteronu w organizmie kobiety. Ponadto, białka pochodzenia roślinnego sa bogate w argininę, niezbędna do wytwarzania tlenku azotu, który pełni funkcję rozluźniająca mięśnie gładkie naczyń, dzięki czemu krew swobodniej płynie przez żeński układ płciowy i ułatwia zagnieżdżenie się embrionu (BATTAGLIA i współaut. 1999).

Następnym czynnikiem wpływającym na gospodarkę hormonalna kobiet jest konsumpcja produktów mlecznych o niskiej zawartości tłuszczu. Takie artykuły spożywcze posiadaja zdecydowanie mniej witaminy D, która jest związkiem steroidowym i może wpływać na procesy reprodukcyjne. Poza tym, technologia odtłuszczania mleka prowadzi do zaburzeń hormonalnych w organizmie, co skutkuje wystapieniem mniejszej ilości estrogenu i progesteronu oraz dominacji męskich hormonów, prowadzac do nieprawidłowych owulacji (CHAVARRO i współaut. 2007a). Badania przeprowadzone w Stanach Zjednoczonych udowodniły, iż podaż w ciagu dnia jednej porcji produktów na bazie mleka odtłuszczonego (np. 1 szklanka mleka), powodowało wzrost prawdopodobieństwa wystąpienia problemów $z$ płodnościa na tle zaburzeń owulacji nawet o 11\%. Natomiast w przypadku produktów na bazie mleka tłustego nastapił $22 \%$ spadek tego ryzyka (ChAvarro i współaut. 2009). Wyniki badań GREENLEGO i współaut. (2003) potwierdziły pozytywna korelację spożywania mleka $z$ 
procesem reprodukcji. U kobiet, które wypijały trzy szklanki mleka $\mathrm{w}$ ciagu dnia, ryzyko niepowodzenia poczęcia dziecka spadło o $70 \% \mathrm{w}$ porównaniu do kobiet, które mleka nie spożywały. Jednak ze względu na duża zawartość tłuszczu i cholesterolu, produkty te moga negatywnie wpływać na układ krwionośny, dlatego ważne jest, aby zachować odpowiednia równowagę we wprowadzaniu tych artykułów spożywczych do codziennej diety (CHAVARRO i współaut. 2009).

\section{WITAMINY I SKŁADNIKI MINERALNE}

Niebagatelna rolę w prawidłowym funkcjonowaniu organizmu człowieka pełnia witaminy. Ich niedobory prowadza do zaburzenia wielu procesów zachodzacych w ustroju, powodując występowanie różnych chorób. Odpowiednia podaż witamin jest również niezmiernie istotna na etapie starania się o potomstwo. Szczególnie ważne w tym przypadku sa witaminy $z$ grupy $B$, takie jak witamina B12, B6 oraz witaminy antyoksydacyjne A, C, E, a także witamina D i kwas foliowy.

Witaminy B12 i B6 maja duże znaczenie w przypadku płodności, poprzez wpływ na znaczny spadek poziomu homocysteiny we krwi i jej przemianę do postaci metioniny bądź cysteiny. Jest to bardzo istotne, ponieważ homocysteina jest aminokwasem, który nie jest powiazany $z$ przemianami białek $i$ uważany jest za przyczynę chorób sercowo-naczyniowych, nowotworów, jak również zaburzeń rozrodczości. Wysoka wartość tego aminokwasu w płynie pęcherzykowym jajnika prowadzi do nieprawidłowego oddziaływania plemnika $z$ komórka jajowa co sprawia, że możliwości poczęcia dziecka ulegaja znacznemu zmniejszeniu (BUHLING i GRAJECKI 2013). Ponadto witamina B6 wpływa na stabilizacje poziomu progesteronu, a $\mathrm{w}$ konsekwencji znacznie zwiększa szansę na poczęcie potomstwa. Zbyt małe stężenie progesteronu powoduje nieprawidłowości fazy lutealnej cyklu miesiaczkowego (HAJDUK 2013). $Z$ kolei nieodpowiednia podaż witaminy B12 skutkuje u kobiet zahamowaniem owulacji oraz niewłaściwa implantacja płodu, natomiast $\mathrm{w}$ męskim nasieniu dochodzi wówczas do znacznego spadku aktywności plemników (SHUKLA i współaut. 2014).

Kwas foliowy jest substancja dobrze znana kobietom w ciąży, bądź planującym potomstwo. Jego suplementacja jest zalecana już na 3 miesiące przed podjęciem starań reprodukcyjnych, a także na początku ciaży. Funkcja folacyny jest przede wszystkim ochrona cewy nerwowej zarodka przed wrodzonymi defektami (RACZYŃSKI i współaut. 2006). Jak wykazały badania przeprowa- dzone przez CHAVARRO i współaut. (2008b), witamina ta, zażywana $\mathrm{w}$ odpowiednich ilościach (ok. $700 \mu \mathrm{g}$ na dobę), powoduje spadek ryzyka niepłodności spowodowanej zaburzeniami owulacji nawet o $40-50 \%$. Kwas foliowy, podobnie jak inne witaminy $z$ grupy B, wpływa na poziom homocysteiny we krwi. Jego niewystarczająca podaż powoduje, że zawartość homocysteiny ulega podwyższeniu, co prowadzi do zaburzeń płodności i nieprawidłowego rozwoju zarodka (HAJDUK 2013). Ponadto, kwas foliowy bierze udział w produkcji i dojrzewaniu plemników oraz $\mathrm{w}$ procesie metylacji materiału genetycznego. Wszystkie te zjawiska ściśle koreluja $z$ procesem reprodukcji (TAMURA i PICCIANO 2006, CHEAH i YANG 2011).

Witamina A zaliczana jest do antyoksydantów. Jej funkcja jest przede wszystkim ochrona organizmu przed wolnymi rodnikami oraz pozytywny wpływ na wzrok. W odniesieniu do płodności kobiet, chroni ona przed powstawaniem infekcji dróg rodnych, poprzez udział w produkcji śluzu chroniacego nabłonek. Reguluje też menstruacje oraz zapewnia odpowiedni rozwój płodu (CETIN i współaut. 2010).

Witamina C jest szeroko wykorzystywana przez organizm człowieka do jego prawidłowego funkcjonowania. W dużych ilościach występuje w tkankach jajnika, przez co jej stała podaż jest istotna podczas fazy lutealnej i owulacji (BUHLING i GRAJECKI 2013). Według HemniEgo i współaut. (2003) znaczne spożycie witaminy $\mathrm{C}$, ok. $500-700 \mathrm{mg}$ dziennie, pozytywnie korelowało ze wzrostem stężenia progesteronu i estrogenów, a w konsekwencji skutkowało zwiększeniem liczby kobiet, które zaszły w ciązęe. Witamina $\mathrm{C}$ korzystnie wpływa także na jakość nasienia $\mathrm{u}$ mężczyzn, ze względu na udział w produkcji hormonów steroidowych, w zatrzymaniu procesu spermaglutynacji, jak również poprzez zabezpieczanie DNA przed utlenieniem (SHUKLA i wpółaut. 2014).

Pozytywne działanie witaminy E opiera się głównie na jej silnych cechach antyoksydacyjnych. Przede wszystkim hamuje ona utlenianie wielonienasyconych kwasów tłuszczowych (PUFA), co jest szczególnie ważne $z$ uwagi na ich wysoka zawartość w plemnikach (WEN 2006). Oprócz ochrony przed uszkodzeniem oksydacyjnym, jej suplementacja może wpływać na wzrost poziomu a-tokoferolu u niepłodnych mężczyzn. Witamina $\mathrm{E}$ wzmacnia również błony komórkowe i chroni erytrocyty przed hemoliza, zatem jej niedobory u kobiet moga skutkować zaburzonymi owulacjami oraz występowaniem poronień czy wad płodu w okresie ciąży (RACZYŃSKI i współaut. 2006). Niezmiernie istotne jest włączenie do diety produktów 
bogatych w witaminę E, gdyż jak wynika $z$ badań przeprowadzonych przez BUHLINGA i GRAJECKIEGO (2013), nawet u 50\% kobiet starajacych się o potomstwo występuja jej niedobory.

Witamina $\mathrm{D}_{3}$ (cholekalcyferol) jest produkowana w skórze człowieka przy udziale światła słonecznego, a jej niedobory moga prowadzić do wystapienia wielu chorób. Badania HoLICKA (2007) udowodniły, iż braki cholekalcyferolu wpływaja na powstawanie insulinooporności i zaburzeń płodności. Niewystarczajaca podaż witaminy $\mathrm{D}_{3}$ powoduje zwiększona produkcję parathormonu, odpowiadajacego za zachowanie prawidłowej równowagi hormonalnej i gospodarki wapniowo-fosforanowej, a zaburzenie tych procesów skutkuje niewłaściwa owulacją i w rezultacie niepłodnościa oraz zwiększonym poziomem męskich hormonów u kobiet, przyczynia się również do zahamowania menstruacji (BRZOZOWSKA i KAROWICZ-BLIŃSKA 2013). ASADI i współaut. (2014) wykazali, że właściwa ilość cholekalcyferolu wpływa na pogrubienie się endometrium, czyli błony śluzowej macicy, dzięki czemu wzrasta odsetek kobiet, które zaszły w ciążę.

Składniki mineralne, podobnie jak witaminy, sa niezbędnymi do zachowania prawidłowej równowagi całego organizmu człowieka ze względu na funkcje jakie pełnia na każdym etapie życia. Mają również swój udział w kształtowaniu płodności.

Żelazo wchodzi w skład czerwonego barwnika krwi, hemoglobiny, odpowiedzialnego za dostarczanie tlenu wszystkim komórkom organizmu. $Z$ niedoborami tego pierwiastka boryka się ok. 1 mln kobiet, na skutek comiesięcznej utraty sporej ilości krwi, wraz $z$ która tracone jest także żelazo (WoŁOWIEC 2013). Przeprowadzone przez CHAVARRo i współaut. (2006) badania udowodniły, iż spożywanie przez kobiety dużych ilości żelaza doprowadziło do poprawy owulacji, a w konsekwencji do spadku zagrożenia zaburzeń płodności, co prawdopodobnie ma zwiazek $z$ funkcja transferyny $w$ jajnikach. Transferyna jest białkiem bioracym udział w zachowaniu odpowiedniej ilości jonów żelaza we krwi i ich dostarczaniu do komórek, jak również do prawidłowego rozwoju gamety żeńskiej i pęcherzyków jajnikowych (ChAvarRo i współaut. 2008c). Ponadto, żelazo podawane przed zajściem w ciążę i w czasie jej trwania, zapobiega powstawaniu wad cewy nerwowej w rozwoju embrionalnym, a także zmniejsza ryzyko przedterminowego porodu (HAJDUK 2013).

Magnez w organizmie nie tylko aktywuje wiele procesów enzymatycznych, bierze udział w produkcji, stabilizacji kwasów nukleinowych i chromosomów czy w metabo- lizmie energetycznym komórek, ale także pełni rolę $\mathrm{w}$ procesach reprodukcji (CETIN i współaut. 2010). Prawidłowa podaż magnezu może zapobiegać powstawaniu nieprawidłowości podczas kształtowania się płodu i nie dopuścić do przedterminowego porodu czy poronienia (HOVDENAK i HARAM 2012). Natomiast jego niedobory maja wpływ na ujawnienie się insulinooporności, a także na nieprawidłowości w sekrecji insuliny, które negatywnie koreluja $z$ płodnościa, powodując zmniejszenie szans na poczęcie potomstwa (JAROSZ 2012). Dodatkowo, braki magnezu wiążą się ze spadkiem stężenia progesteronu (HAJDUK 2013).

W ludzkim ciele znajduje się ponad 200 enzymów zależnych od cynku, bioracych udział w różnych procesach biochemicznych, m.in. w produkcji kwasów nukleinowych czy białek. Jego obecność jest także ważna w syntezie i regulacji hormonalnej, głównie insuliny i tyroksyny (HovDENAK i HARAM 2012). Jest również zaangażowany w wiele funkcji komórkowych, takich jak przekazywanie sygnałów, transkrypcji i replikacji. EBISCH i współaut. (2007) udowodnili, iż cynk wpływa na prawidłowy proces owulacji i cykl menstruacyjny kobiety, przemiany hormonów żeńskich i męskich, także progesteronu. Jego niewystarczająca podaż może prowadzić do nieprawidłowego kształtowania się płodu i porodu przed terminem. Cynk to mikroelement niezbędny do prawidłowego funkcjonowania męskiego układu rozrodczego, o czym świadcza jego wysokie stężenia w męskich narząach płciowych, takich jak prostata, jądra oraz w samych plemnikach (78,9 do $274,6 \mathrm{mg} / 1 \mathrm{w}$ nasieniu). Niedobory tego składnika moga także powodować niewłaściwy rozwój męskich gruczołów rozrodczych, zaburzenia erekcji oraz spadek jakości nasienia. Dlatego niskie poziomy spożycia cynku moga być przyczyną opóźnienia rozwoju jacder, zaburzeń w produkcji testosteronu, a nawet zaprzestania procesu spermatogenezy. Jego podaż, wraz $z$ folianami, powoduje wzrost ilości dobrych jakościowo plemników (KUMAR i SingH 2016).

Selen również jest mikroelementem będacym składnikiem licznych enzymów. Pełni ważna funkcję w przemianach hormonów tarczycy, a także reguluje procesy ochronne i odpornościowe organizmu. Mniejsze ilości selenu w płynie pecherzykowym występowały u kobiet, które borykały się $z$ problemem zajścia w ciażę. Ponadto, niedobory tego składnika moga być przyczyną poronień czy przedwczesnych porodów (MISTRY i współaut. 2012). U mężczyzn, selen wraz z N-acetylocysteina, powoduje zwiększona sekrecję testosteronu oraz spadek zawartości hormonów negatywnie korelujacych $z$ procesem re- 
Tabela 1. Źródła witamin i składników mineralnych w żywności (JAROsZ 2012).

\begin{tabular}{|c|c|c|c|}
\hline Witaminy & Źródło & $\begin{array}{l}\text { Składniki } \\
\text { mineralne }\end{array}$ & Źródło \\
\hline Witamina B6 & $\begin{array}{l}\text { Szpinak, kapusta, awokado, soja, zielony } \\
\text { groszek, fasola, orzechy włoskie i ziem- } \\
\text { ne, banany, nabiał, mięso drobiowe, ryby, } \\
\text { jaja }\end{array}$ & Żelazo & $\begin{array}{l}\text { Watroba, nerki, natka pietruszki, na- } \\
\text { siona roślin straczkowych, mięso, jaja, } \\
\text { ciemne pieczywo }\end{array}$ \\
\hline Witamina B12 & Mięso, ryby, jaja, mleko i jego przetwory & Jod & Skorupiaki, mięczaki, ryby \\
\hline Witamina A & $\begin{array}{l}\text { Olej, wątroba, masło, żółtko jaja, mar- } \\
\text { chew, dynia, papryka, nać pietruszki, } \\
\text { szpinak, botwina }\end{array}$ & Cynk & $\begin{array}{l}\text { Ciemne pieczywo, sery podpuszczko- } \\
\text { we, mięso, wątroba, kasza gryczana, } \\
\text { jaja }\end{array}$ \\
\hline Witamina $\mathrm{C}$ & $\begin{array}{l}\text { Natka pietruszki, czerwona papryka, wa- } \\
\text { rzywa kapustne, owoce jagodowe i cytrusy }\end{array}$ & Selen & $\begin{array}{l}\text { Skorupiaki, ryby, czosnek, grzyby, su- } \\
\text { che nasiona roślin strączkowych }\end{array}$ \\
\hline Witamina $\mathrm{E}$ & $\begin{array}{l}\text { Oleje, oliwa z oliwek, orzechy, migdały, } \\
\text { nasiona słonecznika, dyni, sezamu, awo- } \\
\text { kado, rośliny strączkowe, kiełki pszenicy }\end{array}$ & Magnez & $\begin{array}{l}\text { Przetwory zbożowe, rośliny straczko- } \\
\text { we, orzechy, kakao, gorzka czekolada, } \\
\text { sery podpuszczkowe, ryby, ziemniaki, } \\
\text { warzywa }\end{array}$ \\
\hline Witamina D & $\begin{array}{l}\text { Ryby morskie, oleje rybne, mięso, produk- } \\
\text { ty mleczne }\end{array}$ & & \\
\hline Kwas foliowy & $\begin{array}{l}\text { Ciemnozielone warzywa, produkty pełno- } \\
\text { ziarniste, rośliny strączkowe, owoce }\end{array}$ & & \\
\hline
\end{tabular}

produkcji. Jak podaja CHEAH i YANG (2011), w połaczeniu $z$ witamina $E$ przyczynia się do poprawy parametrów nasienia, jak również wpływa na aktywność męskich komórek rozrodczych (OGUNTIBEJU i współaut. 2009). Badania przeprowadzone przez HURSTA i współaut. (1999) wskazują na istotne znaczenie selenu $\mathrm{w}$ męskiej reprodukcji oraz ścisły zwiazek pomiędzy występowaniem niepłodności męskiej a poziomem selenu (płodni mężczyźni mieli znacznie wyższe zawartości tego składnika w swoim płynie nasiennym niż mężczyźni niepłodni). Również BoITANI i PUGLISI (2008) uważaja selen za istotny dla prawidłowej spermatogenezy ssaków, a jego rola dotyczy obecności głównie dwóch selenoprotein, peroksydazy glutationowej (PHGPx) i selenoproteiny P, które stanowia źródło selenu dla jąder oraz mają wpływ na jakość plemników i męska płodność (HSIEH i SHIN 2012)

Jod jest odpowiedzialny za funkcjonowanie tarczycy, w szczególności za produkcję hormonów: tyroksyny (T4) i trijodotyroniny (T3), które odpowiadaja za prawidłowy przebieg procesów metabolicznych zachodzacych w organizmie. Niewystarczająca podaż jodu skutkuje niedoczynnościa tarczycy oraz wytworzeniem się wola, a zbyt duże jego ilości prowadza do wystąpienia nadczynności tarczycy, poprzez intensywne pobudzenie hormonu tyreotropowego (BUHLING i GRAJECKI 2013). Nieprawidłowa praca tarczycy niekorzystnie wpływa na proces reprodukcji u kobiet, gdyż hormony tarczycy oddziałuja na żeńskie komórki rozrodcze, oocyty, któ- re posiadaja receptory dla trijodotyroniny (HUBALEWSKA-DYDEJCZYK i współaut. 2011). Niedoczynność tarczycy wpływa na zakłócenie cyklu menstruacyjnego, co skutkuje także zaburzeniem owulacji, $z$ powodu wzrostu stężenia męskich hormonów we krwi. Prowadzi to również do rozregulowania gospodarki hormonalnej i negatywnie koreluje $z$ płodnościa (TKACZUK-WŁACH i współaut. 2011) (Tabela 1).

\section{NADWAGA I OTYŁOŚĆ}

Nadwaga i otyłość sa coraz bardziej powszechne wśród społeczeństw różnych krajów. Zostały one uznane przez Światowa Organizację Zdrowia (WHO) za współczesna epidemię, a jak wynika $z$ danych, połowa dorosłych osób na świecie zaliczana jest do grupy ze wskaźnikiem masy ciała BMI (ang. body mass index) przekraczajacym $25 \mathrm{~kg} /$ $\mathrm{m}^{2}$. Nadwaga i otyłość moga prowadzić do groźnych chorób, m.in. chorób sercowo-naczyniowych, cukrzycy czy nowotworów. Ważna konsekwencja tych zjawisk sa problemy z płodnością, występujące zarówno wśród kobiet, jak i mężczyzn (JEZNACH-STEINHAGEN i CZERWONOGRODZKA-SENCZYNA 2013). Wyniki badań NHS II wykazały, iż otyłość ma ogromny wpływ na proces reprodukcji. Istotny jest jej rodzaj, a także poziom zaawansowania (HAJDUK 2012). Szczególnie niebezpieczna jest otyłość typu brzusznego, gdyż wykazuje ona współzależność $z$ insulinoopornością, hiperinsulinemią. Hamuje ona wydzielanie hormonów przysadki i hormonu 


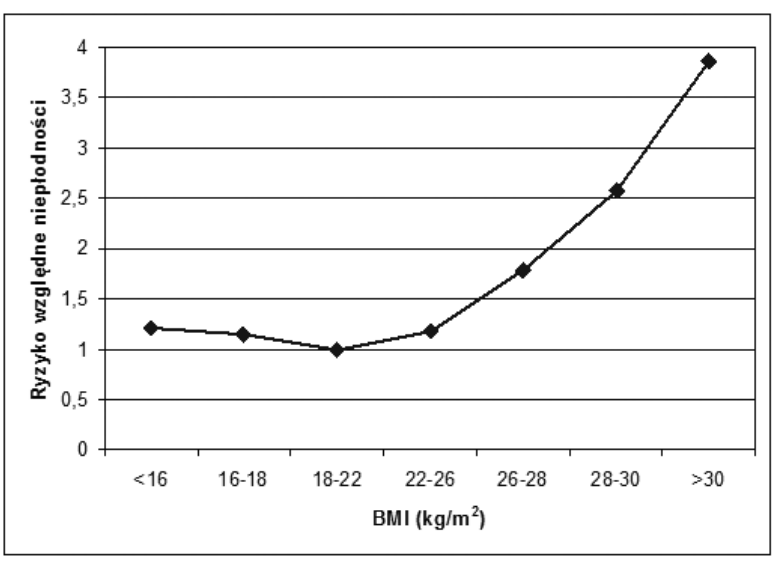

Ryc. 1. Ryzyko niepłodności a BMI (wg Homan i współaut. 2007, zmieniona).

wzrostu, a także przyczynia się do wzrostu konwersji androgenów do estrogenów. Badania Kelestimur i współaut. (2006) wykazały, że otyłość może zmniejszać wydzielanie hormonu wzrostu nawet o 25\%. Dużą rolę odgrywa tu tkanka tłuszczowa, a szczególnie jej funkcja endokrynna. Oprócz magazynowania energii, wpływa także na uwalnianie $i$ funkcjonowanie wielu hormonów. Jednym $z$ nich jest hormon wzrostu, który oddziałuje na hormony płciowe odpowiedzialne za wytwarzanie plemników i komórek jajowych. Nadmiar tkanki tłuszczowej prowadzi do upośledzenia funkcjonowania męskiego układu rozrodczego, zmniejszenia liczby plemników o prawidłowej morfologii i ich stężenia w ejakulacie (KORT i współaut. 2006, Palmer i wpółaut. 2012). Procesy re- produkcyjne ściśle koreluja $z$ wartościa BMI, jak przedstawia Ryc. 1. Podwyższenie BMI o jedna jednostkę wiąże się ze zmniejszeniem wydzielania hormonu wzrostu nawet o 6\% (IRANMANESH i współaut. 1991). Tak samo negatywne działanie zauważono w funkcjonowaniu takich hormonów jak leptyna, rezystyna, grelina $\mathrm{i}$ adiponketyna. Zmiany stężenia hormonów prowadzą do nieprawidłowego wzrostu pęcherzyka, a także rozwoju i zagnieżdżenia się płodu. Powodują również zbyt szybkie dojrzewanie płciowe, co skutkuje zaburzeniem owulacji (Tabela 2) (Gosman i współaut. 2006).

Ponadto, hormony produkowane przez tkankę tłuszczowa przyczyniają się do powstania insulinooporności, hiperinsulinemii, a także niekorzystnie korelują $z$ funkcjami jajników. Działania te prowadza do nieprawidłowej syntezy hormonów płciowych. U kobiet występuje nadmierne wydzielanie androgenów, natomiast u płci męskiej, zahamowanie produkcji testosteronu. Jest to przyczyna ograniczenia procesu powstawania i dojrzewania plemników i skutkuje zaburzeniami erekcji (CHAVARRO i współaut. 2009). JENSEN i współaut. (2004) w swoich badaniach udowodnili, iż nadwaga u mężczyzn powoduje spadek jakości i ilości nasienia. Dokonana przez nich analiza nasienia młodych mężczyzn bez problemów zdrowotnych wykazała, że ejakulat osób $z$ BMI przekraczajacym $25 \mathrm{~kg} / \mathrm{m}^{2}$ charakteryzowal się mniejsza objętościa. Natomiast u mężczyzn w zaawansowanym stadium otyłości, stwierdzono znaczna redukcję liczby plemników. Znaczenie ma także hormon anty-Mullerowski (AMH), który bierze udział $\mathrm{w}$ procesach parakrynnych. U

Tabela 2. Wpływ hormonów wytwarzanych przez tkankę tłuszczową na wrażliwość na insulinę i funkcje rozrodcze (HAJDUK 2012, Gosman i współaut. 2006).

\begin{tabular}{|c|c|c|c|c|}
\hline Hormon & $\begin{array}{l}\text { Zmiana stężenia } \\
\text { hormonu w oty- } \\
\text { łości }\end{array}$ & Działanie & $\begin{array}{l}\text { Wrażliwość na } \\
\text { insulinę }\end{array}$ & $\begin{array}{l}\text { Prawdopodobny wpływ } \\
\text { na reprodukcję }\end{array}$ \\
\hline Adiponektyna & Zmniejszone & $\begin{array}{l}\text { Przyspieszenie utleniania } \\
\text { tłuszczów i wrażliwości na } \\
\text { insulinę }\end{array}$ & Zwiększona & Przyspieszenie owulacji \\
\hline Leptyna & Zwiększone & Działanie anorektyczne & Zwiększona & $\begin{array}{l}\text { Przyspieszenie dojrzewa- } \\
\text { nia płciowego }\end{array}$ \\
\hline $\begin{array}{l}\text { IL-6 } \\
\text { (Interleukina 6) }\end{array}$ & Zwiększone & $\begin{array}{l}\text { Stymulacja wzrostu komó- } \\
\text { rek i białka ostrej fazy }\end{array}$ & Zmniejszona & Upośledzenie implantacji \\
\hline Rezystyna & Zwiększone & $\begin{array}{l}\text { Zwiększenie oporności na } \\
\text { insulinę }\end{array}$ & Zmniejszona & $\begin{array}{l}\text { Upośledzenie implantacji } \\
\text { i owulacji }\end{array}$ \\
\hline $\begin{array}{l}\text { PAI-1 } \\
\text { (inhibitor aktywatora } \\
\text { plazminogenu) }\end{array}$ & Zwiększone & Upośledzenie fibrynolizy & Zmniejszona & Upośledzenie implantacji \\
\hline $\begin{array}{l}\text { TNF-a } \\
\text { (Kacheksyna) }\end{array}$ & Zwiększone & Działanie prozapalne & Zmniejszona & Upośledzenie implantacji \\
\hline
\end{tabular}




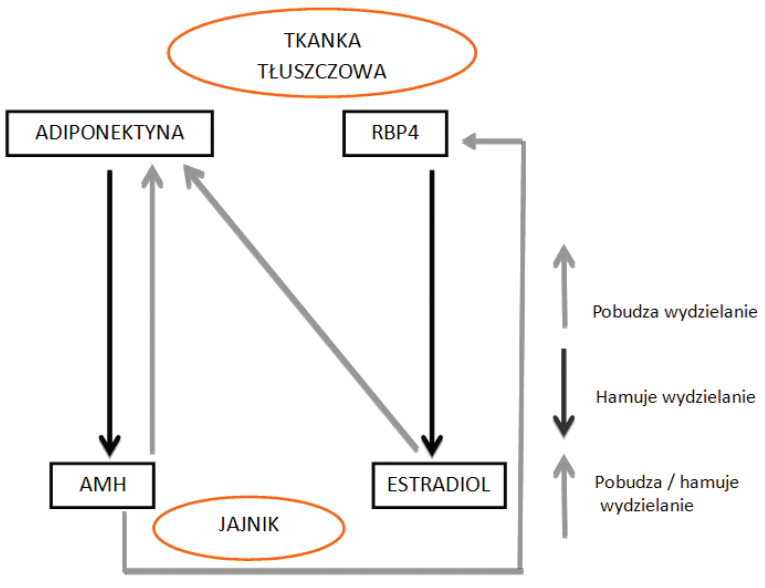

Ryc. 2. Oddziaływanie hormonu anty-Mulerowski AMH na hormony tkanki tłuszczowej (wg WIKAREK i współaut. 2011, zmieniona).

osób $z$ otyłością proces ten jest zmieniony ze względu na zmniejszone stężenie $\mathrm{AMH}$, co upośledza rozwój pęcherzyków i produkcję estradiolu (DURLINGER i współaut. 2002, ANDERSEN i współaut. 2015). Tkanka tłuszczowa zawiera aromatazę katalizujaca konwersję testosteronu do estradiolu, co może wyjaśnić zwiększone stężenie estradiolu u otyłych mężczyzn, szczególnie przy BMI>35 kg/ $\mathrm{m}^{2}$ (HAKONSEN i współaut. 2011). Ilość AMH jest ściśle regulowana przez inne hormony tkanki thuszczowej (Ryc. 2). Hormon ten jest także wykorzystywany w prognozach przywrócenia poprawnych cykli miesiaczkowych $\mathrm{u}$ kobiet po redukcji nadwagi. Nadmiar masy ciała wpływa również na hamowanie sekrecji folitropiny (FSH), lutropiny (LH), a także wydzielania progesteronu przez ciałko żółte (PARIHAR 2003, DE PERGOLA i współaut. 2006, WICKIEWICZ i ZIMMER 2008).

Następstwem otyłości sa także zaburzenia owulacji u kobiet, stanowiace przyczynę niepłodności w 18-30\% występujących przypadków. Kobiety, których BMI przekracza 30 $\mathrm{kg} / \mathrm{m}^{2}$, mają dwukrotnie wyższe ryzyko pojawienia się problemu zajścia w ciążę, spowodowane właśnie tymi nieprawidłowościami (Ryc. 3). Wynika to prawdopodobnie $z$ wrażliwości na insulinę, która jest w dużym stopniu skorelowana $\mathrm{z}$ masa ciała. Wysoka ilość insuliny i glukozy w organizmie powoduje zaburzenia gospodarki hormonalnej i skutkuje zaburzeniami owulacji (LASKOWSKI i współaut. 2016). Częstym zjawiskiem sa także nieprawidłowe cykle menstruacyjne, które mogą być nieregularne, bądź zatracone całkowicie. Równie ważnym parametrem jest wskaźnik talia-biodro (WHR), czyli stosunek obwodu talii do obwodu bioder, wskazujący rozmieszczenie tkanki tłuszczowej. Można wyodrębnić dwa typy otyłości: otyłość trzew- na i otyłość gynoidalna. Pierwsza $z$ nich jest charakterystyczna dla płci męskiej: tkanka tłuszczowa obejmuje górną cześć ciała i okolice brzucha. Ten typ jest szczególnie niekorzystny w procesie reprodukcji. Natomiast otyłość gynoidalna, to otłuszczenie pośladkowo-udowe, często wystepujace u kobiet. Otyłość typu brzusznego powoduje zahamowanie wydzielania insuliny, a także spadek wrażliwości tkanek na jej działanie. Przyrost wskaźnika WHR o 0,1 skutkuje osłabieniem szansy zajścia w ciążę nawet o 30\% (ZAADSTRA i współaut. 1993). Masa ciała ma udowodniony wpływ na proces reprodukcji, gdyż ściśle koreluje $z$ funkcjami hormonalnymi i metabolicznymi organizmu. Spadek ciężaru ciała już o 5\% w stosunku do początkowej, powoduje regulacje menstruacji i procesu owulacji. Poprawia funkcje rozrodcze u kobiet, a tym samym zwiększa szanse na poczęcie dziecka (CROSIGNANi i współaut. 2003).

Niekorzystnym zjawiskiem dla procesu reprodukcji jest nie tylko nadwaga, ale także niedobór masy ciała (FEDORCSAK i współaut. 2004). Zgodnie $z$ wynikami badań CHAVARRO i współaut. (2007b), kobiety których BMI był poniżej normy, sa narażone na podwyższone prawdopodobieństwo wystapienia problemów z zajściem w ciąże o $38 \%$, w zestawieniu $z$ kobietami o prawidłowej wartości wskaźnika BMI. Nagły spadek masy ciała o $30 \%$, wywołany zbyt niska podaża przyjmowanego pokarmu, bądź dużym wysiłkiem fizycznym, może prowadzić do wtórnego zaniku menstruacji (SERDYŃSKA i współaut. 2008). Jest to spowodowane analogicznymi czynnikami, jak w przypadku otyłości. Zmiany te dotycza przede wszystkim zaburzeń hormonalnych i metabolicznych, co wiąże się $z$ zakłóceniem owulacji i miesiączkowa-

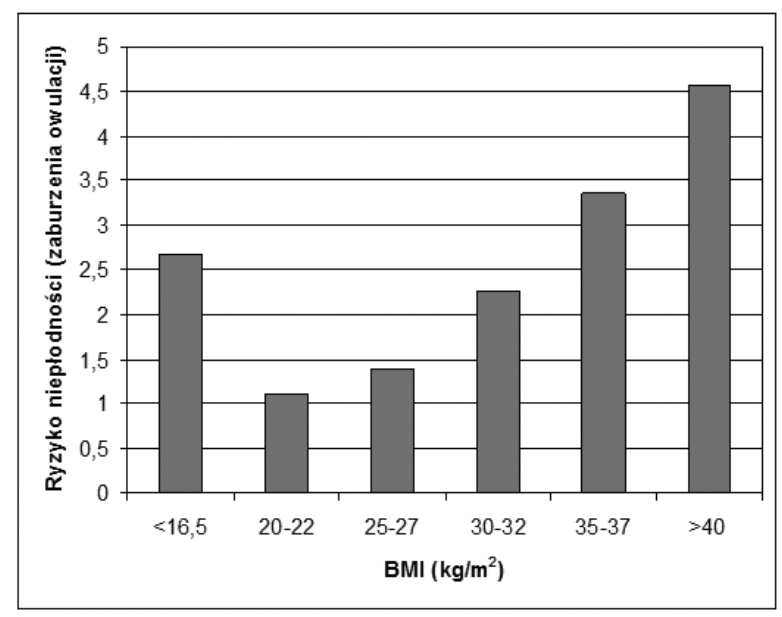

Ryc. 3. Ryzyko niepłodności $z$ powodu zaburzeń owulacji a masa ciała (wg RICH-EDWARDS i współaut. 2002, zmieniona). 
nia. Niedowaga wpływa również na obniżenie poziomu estradiolu, odpowiedzialnego za poprawne działanie układu rodnego kobiet (WIERZEJSKA i JAROSZ 2012). W badaniach RICHA-EDWARDSA i współaut. (2002) określono minimalny poziom wagowy i ilość tkanki tłuszczowej, poniżej których zaczynaja się kłopoty $z$ menstruacją. Wartości te wynosza odpowiednio $48 \mathrm{~kg}$ i 22\%. Problem nieprawidłowej owulacji w $12 \%$ dotyczy kobiet $z$ BMI znacznie poniżej $20 \mathrm{~kg} / \mathrm{m}^{2}$, czego następstwem jest wzrost syntezy hormonu folikulotropowego (FSH) oraz zminimalizowanie czasu trwania fazy ciałka żółtego (FRISCH 1987). Ilość hormonu luteinizującego także ulega znacznemu spadkowi (ZIOMKIEwICZ i współaut. 2008). Zgodnie ze znowelizowanymi w 2009 r. zaleceniami Instytutu Medycyny w USA, prawidłowy wskaźnik BMI kobiet przed zajściem w ciążę został zmieniony i obecnie mieści się w zaleceniach dla całej populacji $18,5-24,9 \mathrm{~kg} / \mathrm{m}^{2}$ (w stosunku do poprzedniego <19,8, uważanego za niezbędny dla optymalnego przebiegu ciaży i stanu zdrowia noworodka) (RASMUSSEN i YAKTINE 2009). Niedowaga jednak nie wiąże się jedynie $z$ zaburzona gospodarka hormonalna, ale również $z$ ubytkami witamin i minerałów w organizmie, co może także zwiększać ryzyko niepłodności.

\section{AKTYWNOŚĆ FIZYCZNA}

Aktywność fizyczna wpływa nie tylko na kondycję, sylwetkę, samopoczucie, ale przede wszystkim na zdrowie. Siedzacy tryb życia nie tylko zwiększa ryzyko incydentów sercowo-naczyniowych i ma negatywny wpływ na gospodarkę węglowodanowo-lipidową, ale może też upośledzać płodność (IGNASZAK-KAUS i JEDRZEJCZAK 2015). Ćwiczenia o umiarkowanym natężeniu zwiększaja szansę na zajście w ciażę u kobiet starajacych się o dziecko, natomiast większa ilość ruchu w postaci spacerów czy jazdy na rowerze może spowodować skrócenie czasu oczekiwania na zajście w ciążę u kobiet, bez względu na ich wagę. Kobiety, których BMI mieści się w normie, na ćwiczenia powinny poświęcać nie mniej niż $30 \mathrm{~min}$. dziennie, natomiast kobiety $z$ nadwaga moga czas ten wydłużyć nawet do 60 min. i więcej. W niektórych przypadkach zaobserwowano poprawę płodności u kobiet $z$ zaburzeniami owulacji dzięki zastosowaniu bardziej intensywnych ćwiczeń jak: bieganie, jogging, czy pływanie (Chavarro i współaut. 2008c).

Wyniki badań uzyskane przez RICHA-EDWARDSA i współaut. (2002) wykazały, że każde dodatkowe $60 \mathrm{~min}$. treningu w tygodniu powoduje spadek ryzyka niepłodności nawet o 7\% (dotyczy to jednak kobiet po- święcających na ćwiczenia minimalnie 5 godzin w tygodniu). Aktywność fizyczna podejmowana przez kobiety powinna być urozmaicona i obejmować ćwiczenia aerobowe, siłowe, rozciągajace, ale również ruch związany $z$ wykonywaniem podstawowych czynności. Duże znaczenie ma odpowiednio skomponowany program ćwiczeń, który wpływa na zmniejszenie otyłości brzusznej, a także na poprawę insulinooporności (SERDYŃSKA i współaut. 2008). Stanowi to ważny czynnik w zakresie poprawy płodności, gdyż tkanka tłuszczowa wydziela wiele hormonów odpowiedzialnych za funkcje rozrodcze (DEMISSIE i MilewicZ 2003).

W przypadku mężczyzn, odpowiednia ilość ruchu wpływa na poprawę jakości nasienia i poziom testosteronu, co potwierdziły badania przeprowadzone przez GASKINSA i współaut. (2015). Mężczyźni, których aktywność fizyczna była na poziomie 12 godzin w tygodniu mieli zdecydowanie większą liczbę plemników (nawet o 73\%). Długie przebywanie w pozycji siedzacej powoduje wzrost temperatury w mosznie, co przyczynia się do zaburzeń spermatogenezy i obniżenia płodności (Jung i ScHUPPE 2007). Jak wykazano już wcześniej, nadmierna masa ciała wpływa negatywnie zarówno na gospodarkę hormonalna, jak i parametry nasienia, a wysiłek fizyczny pomaga w utrzymaniu właściwej masy ciała.

Nie tylko brak aktywności fizycznej, ale także jej nadmierna intensywność opóźnia proces zajścia w ciążę. Wykonywanie zbyt ciężkich i częstych ćwiczeń także może hamować płodność. W dużej mierze dotyczy to kobiet uprawiajacych sport zawodowo. Zjawiskiem często występujacym u młodych kobiet jest tzw. triada sportsmenek, która objawia się zaburzeniami miesiączkowania i owulacji, co jest wynikiem zbyt wyczerpującego, długotrwałego wysiłku, a także niedożywienia $i$ stresu, co $z$ kolei wiąże się $z$ pogorszeniem płodności. W przypadku regularnego, intensywnego wysiłku utrata kilogramów jest czasem mniej zauważalna ze względu na to, iż budowane sa mięśnie. Tkanka tłuszczowa ulega zmniejszeniu, aczkolwiek wzrastajaca tkanka mięśniowa wyrównuje straty w traconych kilogramach. Znaczny ubytek tkanki tłuszczowej zaburza jej funkcję endokrynna, przez co następuja nieprawidłowości w sekrecji jej hormonów (SouZA i Williams 2004). Następuje spadek syntezy estrogenów i zanik owulacji. Ponadto, moga występować zaburzenia fazy lutealnej, a także zaburzenia sekrecji leptyny, lutropiny i gonadoliberyny (CHAVARRO i współaut. 2008c). U sportowców mężczyzn narażonych na przewlekły, intensywny trening poziom testosteronu oraz hormonu lu- 
teinizującego (LH) jest obniżony (tzw. hipogonadyzm zależny od ćwiczeń) (IGNASZAK-KAUS i JĘDRZEJCZAK 2015).

Osoby starajace się o potomstwo, w celu polepszenia swojej płodności, powinny przede wszystkim zachować odpowiednia równowagę $\mathrm{w}$ wykonywaniu ćwiczeń. Każda dawka aktywności fizycznej wykonywana minimum 30 min. dziennie będzie wpływała pozytywnie na układ hormonalny, rozrodczy, a także nerwowy, zarówno w przypadku kobiet, jak i mężczyzn.

\section{UŻYWKI}

Badania potwierdzaja, że w okresie reprodukcji duże znaczenie ma odpowiedni styl życia, aktywność fizyczna i prawidłowa dieta. Używki takie jak: alkohol, nikotyna czy kofeina istotnie wpływaja na płodność i moga znacznie ograniczyć zdolność reprodukcji kobiet i mężczyzn (HomAN i współaut. 2007, SADEU i współaut. 2010).

Alkohol jest jednym $\mathrm{z}$ czynników, które negatywnie koreluja $z$ płodnościa (Ryc. 4). Jego nadmierne spożycie, a czasem nawet niewielka ilość wystarczy, aby nastapiła dysfunkcja wielu układów organizmu. Odzwierciedleniem sa nieprawidłowe cykle menstruacyjne, bezpłodność czy wystapienie poronień u kobiet spodziewających się dziecka (CURTIS i wspólaut. 1997). Nieprawidłowe miesiaczkowanie może pojawić sie już u kobiet okazjonalnie spożywajacych alkohol. Wysokie spożycie alkoholu wśród kobiet zwiazane jest ze zwiększonym ryzykiem bezpłodności (EGGERT i współaut. 2004). Badania przeprowadzone przez WILSNACK i współaut. (1984) wykazały, że spożycie 90 $\mathrm{ml}$ alkoholu na dobę, doprowadziło do uzyskania najwyższego (30\%) poziomu bezpłod-

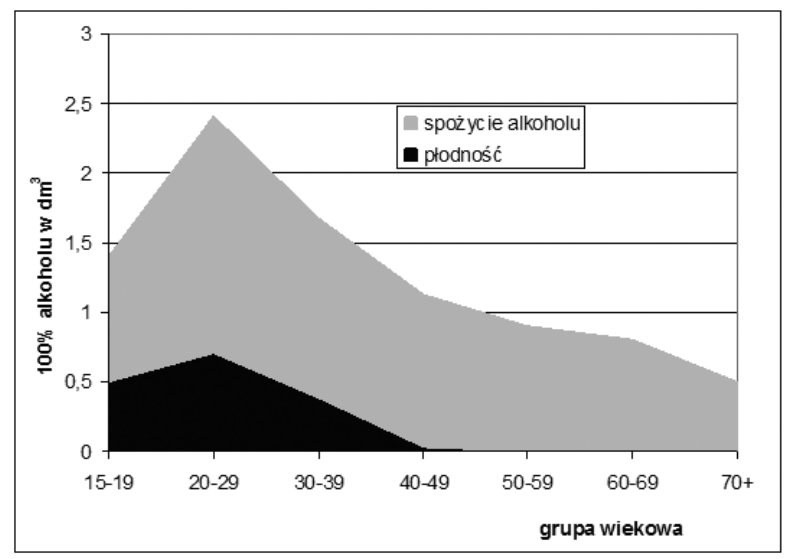

Ryc. 4. Spożycie alkoholu a płodność (liczba urodzeń żywych na 10 kobiet w odpowiednim wieku) (wg MOSKALEwICZ 2007, zmieniona). ności wśród amerykańskich kobiet. Z kolei inne badania dowiodly, iż ryzyko wystapienia zaburzeń płodności $z$ powodu nieprawidłowej owulacji jest wyższe o $1,3 \%$ u kobiet spożywających nie więcej niż $100 \mathrm{~g}$ alkoholu tygodniowo, natomiast u kobiet przyjmujacych ponad $100 \mathrm{~g}$ alkoholu na tydzień prawdopodobieństwo to wzrasta do $1,6 \%$ (GRODSTEIN i wspólaut. 1994). Nadużywanie alkoholu prowadzi również do endometriozy, która jest kolejną z przyczyn występowania niepłodności wśród kobiet. Następstwem spożywania alkoholu jest także wytwarzanie $\mathrm{w}$ organizmie reaktywnych form tlenu, co skutkuje stresem oksydacyjnym negatywnie wpływającym na płodność (ŚWIDERSKAKoŁACZ i współaut. 2012). U mężczyzn stres oksydacyjny powoduje uszkodzenie komórek rozrodczych i spadek ich aktywności. Z badań wynika, iż jest to przyczyna 30-80\% występujących przypadków zaburzeń męskiej płodności (JEZNACH-STEINHAGEN i CZERWONOGRODZKA-SENCZYNA 2013). Konsumpcja alkoholu przez mężczyzn może powodować impotencję, zmniejszenie libido i niekorzystnie wpływać na jakość plemników (Homan i współaut. 2007). W większości badań stwierdzono, że spożycie alkoholu wpływa na niepłodność męską poprzez zmniejszenie objętości nasienia, zwiększenie liczby plemników o nieprawidłowej morfologii i wywołanie leukocytospermii (TKACZUK-WEACH i współaut. 2006, SADEU i współaut. 2010, LA VigneRA i współaut. 2013). PAJARINEN i współaut. (1996) wykazali, że spożywanie alkoholu w ilości >8 drinków/tydzień lub >40 g/dobę zakłócało spermatogenezę, spożycie alkoholu $>80 \mathrm{~g} /$ dobę powodowało częściowe lub całkowite zatrzymanie tego procesu.

Palenie papierosów jest kolejnym czynnikiem powodujacym osłabienie zdolności reprodukcyjnej. $\mathrm{Na}$ zaburzenia płodności sa narażone nie tylko osoby aktywnie palace papierosy, ale również te, które przebywaja $\mathrm{w}$ ich otoczeniu, czyli tak zwani bierni palacze. Badania toksyczności dymu tytoniowego jasno potwierdzaja fakt, iż zawiera on wiele substancji szkodliwych dla człowieka (ADAMEK i współaut. 2003). Wpływ dymu papierosowego na rozrodczość kobiet został poparty badaniami HOMANA i współaut. (2007), w których stwierdzono, że palenie tytoniu prowadzić może do spadku stężenie hormonu lutenizującego oraz wzrostu poziomu hormonu folikulotropowego, co negatywnie działa na proces owulacji. Substancje zawarte $\mathrm{w}$ dymie tytoniowym zakłócaja proces kształtowania się ciałka żółtego oraz powoduja niekorzystne zmiany $\mathrm{w}$ oocytach. Dodatkowo, składniki te wpływaja na spadek ilości i jakości pęcherzyków jajnikowych, prowadza także do uszkodzenia DNA. 
Niekorzystnie wpływają na jajowody, gdzie zaburzony zostaje proces aktywności rzęsek i zwielokrotnienie ilości skurczów, co powoduje niemożność zagnieżdżenie się zarodka. Nikotyna powoduje osłabienie rozrodczości kobiet, a także zwiększone prawdopodobieństwo (2-3-krotne) wystapienia niepłodności (CURTis i współaut. 1997).

Nikotyna negatywnie wpływa również na materiał genetyczny męskich komórek rozrodczych, powodujac jego destrukcję. Ponadto, ma wpływa wzrost poziomu białych krwinek, zaburzenia męskiej gospodarki hormonalnej oraz ogólne pogorszenie się jakości ejakulatu. Zjawisko to postepuje wraz $Z$ upływem czasu i intensywnościa palenia papierosów (TKACZUK-WŁACH i współaut. 2006). U palących mężczyzn obserwuje się spadek ilości plemników o 23\% i ich ograniczona aktywność, zmniejszona o $13 \%$ w porównaniu $z$ osobami niepalacymi (SELI 2011).

Kofeina jest substancja zawarta nie tylko w kawie, ale także w herbacie czy kakao. Można ją również spotkać w napojach energetycznych. Nie zawsze zatem konsument ma świadomość dostarczania jej organizmowi, a według badań, spożywana jest aż przez 80\% społeczeństwa (JAROsz i współaut. 2009). Wielokrotnie analizowano wpływ kofeiny na rozrodczość kobiet, jednoznacznie potwierdzając fakt, że jej spożycie nie wywiera pozytywnego działania na płodność. Zwiększona dzienna podaż kofeiny (ok. 5 filiżanek) powoduje większe prawdopodobieństwo pojawienia się zaburzeń płodności, nawet o $45 \%$, a czas oczekiwania na potomstwo może wydłużyć się o 9,5 miesiąca (BOLÚMAR i współaut. 1997). Według DIXONA i współaut. (2011) kofeina utrudnia przeniesienie żeńskiej komórki rozrodczej do macicy, co może skutkować brakiem implantacji zarodka. Natomiast wyniki badań ScHLIEPA i współaut. (2012) wykazały, iż substancja ta powoduje spadek stężenia estradiolu. Brak jest natomiast badań potwierdzajacych negatywne działanie kofeiny na męska płodność (SELI 2011).

\section{PODSUMOWANIE}

Dieta i styl życia maja istotne znaczenie w zaburzeniach płodności występujących u kobiet i mężczyzn. Ogromny wpływ na procesy reprodukcyjne maja nawyki żywieniowe oraz codzienne zachowania zwiazane $z$ aktywnością fizyczną czy stosowaniem używek.

Niezmiernie ważną rolę odgrywa właściwa podaż makroskładników (tłuszczów, węglowodanów i białek) w codziennym jadłospisie osób starających się o dziecko. Istotne jest, aby dieta dostarczała jak najwięcej nienasyconych kwasów tłuszczowych, kosztem na- syconych i izomerów trans. $Z$ jadłospisu należy usunać utwardzane margaryny, ciasta, chipsy, a wzbogacić o ryby morskie oraz oleje pochodzenia roślinnego, np. olej lniany. Równie istotne jest spożywanie produktów pełnoziarnistych $z$ dużą zawartością błonnika, natomiast $z$ diety powinny zostać wyeliminowane wysoko przetworzone produkty, w tym białe pieczywo, makarony oraz słodycze. Wyniki badań dotyczacych zaburzeń rozrodczości wskazują, że najlepszym sposobem na zmniejszenie problemu niepłodności jest zwiększenie udziału białek roślinnych (fasola, soja, soczewica) kosztem białek zwierzęcych (zwłaszcza czerwonego mięsa i odtłuszczonych produktów mleczarskich). Nie można także zapomnieć o roli witamin i składników mineralnych, dlatego ważne jest, aby dieta była bogata w w świeże warzywa, owoce, ryby i nasiona.

Masa ciała ma udowodniony wpływ na proces reprodukcji, przy czym istotny jest właściwy wskaźnik BMI, gdyż zarówno nadmiar masy ciała, jak i jej niedobór moga znacząco zaburzać ten proces. Najlepszy rezultat można osiagnaćc przez stosowanie odpowiedniej diety $\mathrm{W}$ połaczeniu $\mathrm{Z}$ właściwie dobrana aktywnością fizyczną.

Odżywianie się i styl życia niewątpliwie należą do najbardziej niedocenionych czynników, które maja istotny wpływ na zachowanie zdrowia i płodności, dlatego też powinny być szczególnie brane pod uwagę przez przyszłych rodziców.

\section{Streszczenie}

Zaburzenia płodności maja zwiąek nie tylko $z$ wiekiem (starzenie się jajników i jąder oraz pogarszanie się jakości gamet), ale również wynikaja $z$ negatywnego wpływu czynników środowiskowych, zawodowych i stylu życia. Do elementów stylu życia zalicza się sposób żywienia, aktywność fizyczna oraz palenie papierosów i spożywanie alkoholu. W pracy omówiono rolę poszczególnych składników odżywczych, takich jak: białka, węglowodany, tłuszcze, witaminy i składniki mineralne w kontekście procesów reprodukcyjnych. Nieprawidłowy sposób żywienia, nadmiar lub niedobór masy ciała to czynniki, które w znacznym stopniu moga wpływać na płodność zarówno kobiet, jak i mężczyzn.

\section{LITERATURA}

AdameK A., ANholcer A., Florek E., ADAmeK R., 2003. Ocena wpływu biernego narażenia kobiet na dym tytoniowy $w$ czasie ciaży na mase urodzeniowa $i$ parametry życiowe noworodka. Gin. Prakt. 11, 24-27.

ANDERSEN J. M., HeRning H., Aschim E. L., HJELMES ÆTH J., MALA T., HANEVIK H. I., WITCZAK O., 2015. Body mass index is associated with impaired semen characteristics and reduced levels of Aanti-Müllerian hormone across a wide weight range. PLoS One 10, e0130210.

Asadi M., Matin N., Frootan M., Mohamadpour J., QORBANI M., TANHA F. D., 2014. Vitamin D 
improves endometrial thickness in PCOS women who need intrauterine insemination: a randomized double-blind placebo-controlled trial. Arch. Gynecol. Obstet. 289, 865-870.

AtTAMan J. A., TOTH T. L., Furtado J., Campos H., Hauser R., ChavarRo J. E., 2012. Dietary fat and semen quality among men attending a fertility clinic. Hum. Reprod. 27, 1466-1474.

Battaglia C., Salvatori M., Maxia N., Petraglia F., FACChinetTI F., VolPe A., 1999. Adjuvant a-arginine treatment for in-vitro fertilization in poor responder patients. Hum. Reprod. 14, 1690-1697.

BoITANI C., PÚglisi R., 2008. Selenium, a key element in spermatogenesis and male fertility. [W:] Molecular mechanisms in spermatogenesis. CHENG C.Y. (red.). Springer New York, 65-73.

Boivin J., Bunting L., Collins J. A., NYGRen K. G., 2007. International estimates of infertility prevalence and treatment seeking: potential need and demand for infertility medical care. Hum. Reprod. 22, 1506-1512.

Bolúmar F., Olsen J., Rebagliato M., Bisanti L., 1997. Caffeine intake and delayed conception a European multicenter study on infertility and subfecundity. European Study Group on Infertility Subfecundity. Am. J. Epidemiol. 145, 324-334

Brzozowska M., KaRowiCZ-BlińsKa A., 2013. Rola niedoboru witaminy $D w$ patofizjologii zaburzeń wystepujacych $w$ zespole policystycznych jajników. Ginekol. Pol. 84, 456-460.

BUHLING K. J., GRAJECKI D., 2013. The effect of micronutrient supplements on female fertility. Curr. Opin. Obstet. Gynecol. 25, 173-180.

Cetin I., Berti C., Calabrese S., 2010. Role of micronutrients in the periconceptional period. Hum. Reprod. 16, 80-95.

ChavarRo J. E., Rich-EDWARds J. W., Rosner B. A., WilletT W. C., 2006. Iron intake and risk of ovulatory infertility. Obstet. Gynecol. 108, 1145-1152.

CHAVARRO J. E., Rich-EDWARDS J. W., WilletT W. C., 2007a. A prospective study of dairy foods intake and anovulatory infertility. Hum. Reprod. 22, 1340-1347.

ChavarRo J. E., Rich-EdWARdS J. W., Rosner B. A., Willett W. C., 2007b. Diet and lifestyle in the prevention of ovulatory disorder infertility. Obstet. Gynecol. 110, 1050-1058.

CHAVARRO J. E., RICH-EDWARDS J. W., ROSNER B. A., WilletT W. C., 2007c. Dietary fatty acid intakes and the risk of ovulatory in-fertility. Am. J. Clin. Nutr 85, 231-237.

ChAVARRO J. E., Rich-EDWARDS J. W., RosNER B. A., WilletT W. C., 2008a. Protein intake and ovulatory infertility. Am. J. Obstet. Gynecol. 198, 210 e211-217.

ChavarRo J. E., Rich-EDWARds J. W., Rosner B. A., WilletT W. C., 2008b. Use multivitamins, intake of $B$ vitamins and risk of ovulatory in fertility. Fertil. Steril. 89, 668-676.

Chavarro J. E., WilletT W. C., SkerretT P. J., 2008c. The fertility diet: Groundbreaking research reveals natural ways to boost ovulation \& improve your chances of getting pregnant. McGraw-Hill, New York.

ChaVARRO J. E., RICH-EDWARDS J. W., ROSNER B. A., WilletT W. C., 2009. A prospective study of dietary carbohydrates quantity and quality in relation to risk of ovulatory infertility. Eur. J. Clin. Nutr. 63, 78-86.

CHAVARRO J. E., FURTADO J., TOTH T. L., FORD J., Keller M., Campos H., HaUser R., 2011. Trans-fatty acid levels in sperm are associated with sperm concentration among men from an infertility clinic. Fertil. Steril. 95, 1794-1797.

ChavarRo J. E., Minguez-Alarcon L., Mendiola J., Cutillas-Tolin A., LOPEZ-Espin J. J., TORRES-CANTERO A. M., 2014. Trans fatty acid in take is inversely related to total sperm count in young healthy men. Hum. Reprod. 29, 429-440.

CHEAH Y., YANG W., 2011. Functions of essential nutrition for high quality spermatogenesis. Adv. Biosci. Biotechnol. 2, 182-197.

CichON R., WĄDOŁOWSKA L., 2010. Weglowoda ny. [W:] Żywienie człowieka. Podstawy nauki o żywieniu. GAWECKI J. (red.). Wyd. Naukowe PWN, Warszawa, 155-180.

CoHen S., 2011. Przeglad kliniczny: niepłodność. [W:] Radiologia interwencyjna chorób kobiet. ANDREWS R., BRODIE M., ChWALISZ K. (red). Wydawnictwo Lekarskie PZWL, Warszawa, 11, 117-125.

COMHAIRE F., 2010. The role of food supplementation in the treatment of the infertile couple and for assisted reproduction. Andrologia 42, 33140.

Crosignani P. G., Colombo M., Vegetti W., SoMIGLIANA E., GESSATI A., RAGNI G., 2003. Overweight and obese anovulatory patients with polycystic ovaries: parallel improvements in anthropometric indices, ovarian physiology and fertility rate induced by diet. Hum. Reprod. 18, 1928-1932.

CurTiS K. M., SAViTZ D. A., ARBUCKLE T. E., 1997. Effects of cigarette smoking, caffeine consumption and alcohol intake on fecundability. Am. J. Epidemiol. 146, 32-41.

De Pergola G., Maldera S., Tartagni M., PanNACCIULli N., LOVERRO G., GIORGinO R., 2006. Inhibitory effect of obesity on gonadotropin, estradiol, and inhibin $B$ levels in fertile women. Obesity 14, 1954-1960.

Demissie M., MilewiCZ A., 2003. Zaburzenia hormonalne $w$ otyłości. Diabetol. Prakt. 3, 207209.

DiXON R., HWANG S. J., BRITTON F. C., SANDERS K. M., WARD S. M., 2011. Inhibitory effect of caffeine on pacemaker activity in the oviduct is mediated by cAMP-regulated conductances. Br. J. Pharmacol. 163, 745-754.

DURLinger A. L., GRUIJTERS M. J., KRAMER P., Karels B., Ingraham H. A., Nachtigal M. W., Uilenbroek J. T., Grootegoed J. A., ThemMEN A. P., 2002. Anti-Müllerian hormone inhibits initiation of primordial follicle growth in the mouse ovary. Endocrinology 143, 10761084.

Ebisch I., Thomas C. M., Peters W. H., BRAat D. D., Steegers-Theunissen R. P., 2007. The importance of folate, zinc and antioxidantsin the pathogenesis and prevention of subfertility. Hum. Reprod. Update 13, 163-174.

EGGERT J., THEOBALD H., ENGFELDT P., 2004. Ef fects of alcohol consumption on female fertility during an 18-year period. Fertil. Steril. 81, 379-383.

Fedorcsak P., Dale P. O. Storeng R., ERTZEid G., BJERCKE S., OLDEREID N., OMLAND A. K., ABYHOLM T., TANBO T., 2004. Impact of overweight and underweighton assisted reproduction treatment. Hum. Reprod. 19, 2523-2528.

FRISCH R. E., 1987. Body fat, menarche, fitness and fertility. Hum. Reprod. 2, 521-533.

GASKINS A. J. MENDIOLA J., AFEICHE M. JøRGENSEN N., SwAN S. H., CHAVARRO J. E., 2015. Physical activity and television watching in relation to semen quality in young men. Br. J. Sports Med. 49, 265-270. 
Gosman G. G., Katcher H. I., LEGRO R. S., 2006. Obesity and the role of gut and adipose hormones in female reproduction. Hum. Reprod. Update 12, 585-601.

Greenlee A. R., ARBuckle T. E., Chyou P. H., 2003. Risk factor for female infertility in an agricultural region. Epidemiology 14, 429-436.

Grodstein F., Goldman M. B., CRAMER D. W. 1994. Infertility in women and moderate alcohol use. Am. J. Public. Health 84, 14291432.

HAJDUK M., 2012. Wpływ masy ciała na płodność u kobiet. Endokrynol. Otył. Zab. Przem. Mat. 8, 93-97.

HAJDUK M., 2013. Wpływ wybranych składników pokarmowych na funkcjonowanie układu rozrodczego u kobiet. Endokrynol. Otył. Zab. Przem. Mat. 9, 29-33.

HaKONSEN L. B., THulstrup A. M., Aggerholm A. S., OLSEN J., BONDE J. P., ANDERSEN C. Y., Bungum M., ERnst E. H., Hansen M. L., ERnst E. H., Ramlau-Hansen C. H., 2011. Does weight loss improve semen quality and reproductive hormones? Results from a cohort of severely obese men. Reprod. Health 8, 24.

Hemni H., Endo T., Kitajima Y., MANASE K., Hata H., KUDO R., 2003. Effect of ascorbic acid supplementation and serum progesterone levels in patients with luteal chase defect. Fertil. Steril. 80, 459-461.

Holick M., 2007. Vitamin D deficiency. New Engl. J. Med. 357, 266-281.

Holmes M. D., Pollak M. N., Willett W. C., HANKINSON S. E., 2002. Dietary correlates of plasma insulin-like growth factor I and insulin-like growth factor binding protein 3 concentration. Cancer Epidemiol. Biomarkers Prev. $11,852-861$.

Homan G. F., Davies M., Norman R., 2007. The impact of lifestyle factors on reproductive performance in the general population and those undergoing infertility treatment: a review. Hum. Reprod. 13, 209-223.

Hosseini B., Eslamian G., 2014. Association of dietary factors with male and female infertility: review of current evidence. Thrita 3, e20953.

HOVDENAK N., HARAM K., 2012. Influence of mineral and vitamin supplements on pregnancy outcome. Eur. J. Obstet. Gynecol. Reprod. Biol. 164, 127-132.

HsieH T. C., ShIN P., 2012. Nutritional pathways to protect male reproductive health. [W:] Male infertility: Contemporary clinical approaches, andrology, art \& antioxidants. PAREKATTIL S. J., AGARWAL A. (red.). Springer Science Business Media, LLC, 34, 363-367.

HubALEWSKA-DYDEJCZYK A., LEWIŃSKI A., MILEWICZ A., RADOWICKI S., POREBA R., KARBOWNIK-LEWIŃSKA M, KOSTECKA-MATYJA M., TROFIMIUK-MÜldNER M., PACH D., ZYGMUNT A., 2011. Postepowanie $w$ chorobach tarczycy $u$ kobiet $w$ ciaży. Pol. J. Endocrinol. 62, 362-381.

Hurst R., BAO Y. P., RIDley S., 1999. Phospholipid hydroperoxide cysteine peroxidase activity in human serum. Biochem. J. 38,723.

IGNASZAK-KAUS N., JĘDRZEJCZAK P., 2015. Wpływ sportu na meeski układ rozrodczy. Post. Androl. 2, 34-40.

IRANMANESH A., LIZARRALDE G., VELDHUIS J. D., 1991. Age and relative adiposity are specific negative determinants of the frequency and amplitude of growth hormone (GH) secretory bursts and the half-life of endogenous $G H$ in healthy men. J. Clin. Endocrinol. Metab. 73, 1081-1088.
JAROSZ M., 2012. Witaminy. [W:] Normy żywienia dla populacji polskiej - nowelizacja. JAROSZ M. (red.). Wyd. IŻŻ, Warszawa, 6-122.

JAROSZ M., WIERZEJSKA R., MOJSKA H., ŚwIDERSKA K., SiUBA M., 2009. Zawartość kofeiny $w$ produktach spożywczych. Bromat. Chem. Toksykol. 42, 776-781.

Jensen T. K., Andersson M. N. JøRGensen N., Andersen A. G., CARlsen E., Petersen J. H., SKAKKEBAEK N. E., 2004. Body mass index in relation to semen quality and reproductive hormones among 1,558 Danish men. Fertil. Steril. 82, 863-870.

JEZNACH-STEINHAGEN A., CZERWONOGRODZKA-SENCZYNA A., 2013. Postepowanie dietetyczne jako element leczenia zaburzeń płodności u mężczyzn $z$ obniżona jakościa nasienia. Endokrynol. Otył. Zab. Przem. Mat. 9, 14-19.

JUNG A., SChUPPE H. C., 2007. Influence of genital heat stress on semen quality in humans. Andrologia 6, 203-215.

Kelestimur F., Popovic V., Leal A., Van Dam P. S., Torres E., Perez Mendez L. F., Greenman Y., KoppeschaAR H. P., Dieguez C., CasanueVA F. F., 2006. Effect of obesity and morbid obesity on the growth hormone (GH) secretion elicited by the combined GHRH + GHRP- 6 test. Clin. Endocrinol. 64, 667-671.

KOCHAN Z., KARBOWSKA J., BABICZ-ZIELIŃSKA E., 2010. Trans-kwasy thuszczowe $w$ diecie - rola $w$ rozwoju zespołu metabolicznego. Post. Hig. Med. Dośw. 64, 650-658.

KorT H. I., MASSEy J. B., Elsner C. W., MitCHELl-LeEF D., ShapiRo D. B., WitT M. A., ROUDEBUSH W. E., 2006. Impact of body mass index values on sperm quantity and quality. J. Androl. 27, 450-452.

KumAR N., SingH A. K., 2016. Role of zinc in male infertility: review of literature. Ind. J. Obstet. Gynecol. Res. 3, 167-171.

LA Vignera S., CONDORElli R. A., BAlercia G., VicARI E., CAlOGERO A. E., 2013. Does alcohol have any effect on male reproductive function? A review of literature. Asian J. Androl. $15,221-225$.

LASKOWSKI D., SJunNesson Y., Humblot P., ANDERSSON G., GUSTAFSSON H., BÅGE R., 2016. The functional role of insulin in fertility and embryonic development-What can we learn from the bovine model? Theriogenology 86, 457-464.

ŁoŹNA K., KiTA A., STYCZYŃSKA M., BIERNAT J., 2012. Skład kwasów tłuszczowych olejów zalecanych $w$ profilaktyce chorób cywilizacyjnych. Probl. Hig. Epidemiol. 93, 871-875.

MARCINIAK-ŁUKASIAK K., 2011. Rola i znaczenie kwasów tłuszczowych omega-3. Żywność Nauka Technol. Jakość 6, 24-35.

Missmer S. A., ChavarRo J. E., MAlspeis S., BERTONE-JOHNSON E. R., HORNSTEIN M. D., Spiegelman D., Barbieri R. L., Willett W. C., HANKINSON S. E., 2010. A prospective study of dietary fat consumption and endometriosis risk. Hum. Reprod. 25, 1528-1535.

Mistry H. D., PiPkin F. B., Redman C. W., PosTON L., 2012. Selenium in reproductive health. Am. J. Obstet. Gynecol. 206, 21-30.

Moskalewicz J., 2007. Problemy zdrowia prokreacyjnego zwiazane $z$ konsumpcja alkoholu. Alkohol Narkom. 20, 55-63.

Oguntibeju O. O., EsterhuYse J. S., TRuter E. J., 2009. Selenium: its potential role in male infertility. Pak. J. Med. Sci. 25, 332-337.

PAJARINEN J., KARHUNEN P. J. , SAVOLAINEN V., Lalu K., PentTila A., LaipPala P., 1996. Moderate alcohol consumption and disorders of 
human spermatogenesis. Alcohol Clin. Exp. Res. 20, 332-337.

Palmer N. O., BaKos H. W., Fullston T., LANe M., 2012. Impact of obesity on male fertility, sperm function and molecular composition. Spermatogenesis 2, 253-263.

PARIHAR M., 2003. Obesity and infertility. Rev. Gyneacol. Pract. 3, 120-126.

PRZYSEAWSKI J., GÓRNA I., FlOREK E., SZYMANOWSKI K., 2010. Rola wybranych składników pożywienia $w$ profilaktyce niepłodności u kobiet. Bromat. Chem. Toksykol. 42, 138-144.

RACZYŃSKI P., KUBIK P., NIEMIEC T., 2006. Zalecenia dotyczace suplementacji diety $u$ kobiet podczas planowania ciaży, $w$ ciaży $i w$ czasie karmienia piersia. Ginekol. Prakt. 4, 2-7.

RAPORT (Raport Koalicji na rzecz Kompleksowej Terapii Niepłodności), 2015. Wspieramy płodność. Warszawa 2015.

RASMUSSEN K. M., YAKTINE A. L., 2009. Weight gain during pregnancy. Reexamining the Guidelines. Institute of Medicine and National Research Council. The National Academies Press, Washington, D.C.

REICHMAN M., JUDD J., TAYLOR P., NAIR P., JONES D., CAMPBELL W., 1992. Effect of dietary fat on length of the follicular phase of the menstrual cycle in a controlled diet setting. J. Clin. Endocrinol. Metab. 74, 1171-1175.

Rich-EDWARDS J. W., SPIEGElman D., GaRland M., Hertzmark E., HunTer D. J., Colditz G. A., Willet W. C., Wand H., Manson J. E., 2002. Physical activity, body mass index, and ovulatory disorder infertility. Epidemiology 13, 184190.

RoszKOWsKI W., RoszKowsKA H., 2009. Epidemiologia żywieniowa. [W:] Żywienie człowieka a zdrowie publiczne. GAWĘCKI J., ROSZKOWSKI W. (red.). Wyd. Naukowe PWN, Warszawa, 56-67.

Sadeu J. C., Hughes C. L., Agarwal S., Foster W. G., 2010. Alcohol, drugs, caffeine, tobacco, and environmental contaminant exposure: reproductive health consequences and clinical implications. Crit. Rev. Toxicol. 40, 633-652.

SaRavanan N., HASEeb A., EHTESHAM N. Z., GHAFOORUNISSA, 2005. Differential effects of dietary saturated and trans-fatty acids on expression of genes associated with insulin sensitivity in rat adipose tissue. Eur. J. Endocrinol. $153,159-165$

SchlieP K. C., Schisterman E. F., Mumford S. L., Pollack A. Z., Zhang C. J., Ye A., StanFORD J. B., HAMMOUND A. O., PORUCZNIK C. A., WACTAWSKI-WENDE J., 2012. Caffeinated beverage intake and reproductive hormones among premenopausal women. Am. J. Clin. Nutr. 95, 488-497.

Seli E., 2011. Niepłodność. Ginekologia w Praktyce Klinicznej 1, 12-13.
SERDYŃSKA M., PAWELCZYK L., JEDRZEJCZAK P., 2008. Epidemiologia niepłodności. [W:] Ginekologia. SŁomKo Z. (red.). Wyd. Lekarskie PZWL, Warszawa, 465-470.

SHUKLA G., SARIKA M., SARITHA D., SAMPATH KUMAR C. J., 2014. Nutritional therapy for male infertility. J. Pharma. Creat. 1, 11-16.

SouzA M. J., Williams N. I., 2004. Physiological aspect and clinical squeal of energy deficiency and hyperestrogenism in exercising women. Hum. Reprod. 10, 433-448.

SZOSTAK-WEGIEREK D., 2011. Sposób żywienia a płodność. Med. Wieku Rozw. 4, 431-436.

ŚWiATKOWSKA D., 2013. Żywienie a płodność. Dieta kobiet w wieku prokreacyjnym. Pediatr. Med. Rodz. 9, 102-106.

ŚWIDERSKA-KOEACZ G., KUMAŃSKI K., PARKA B., 2012. Alkohol a stres oksydacyjny. Kosmos 61, 93-103.

TAMURA T., PICCIANO M. F., 2006. Folate and human reproduction. Am. J. Clin. Nutr. 83, 993-1014.

TKACZUK-WŁaCH J., ROBAK-CHOŁUBEK D., JAKIEL G., 2006. Niepłodność męska. Prz. Menopauz. 5, 333-338.

TKACZUK-WŁaCH J., SOBSTYL M., JAKIEL G., 2011. Choroby tarczycy a czynność jajników. Prz. Menopauz. 6, 504-507.

WEN J. C., 2006. The role of vitamin $E$ in the treatment of male infertility. Nutr. Bytes 11, 1-6.

WiCKIEWICZ D., ZIMMER M., 2008. Otyłość a problem niepłodności u kobiet. Perinatol. Neonatol. Ginekol. 1, 138-140.

WIERZEJSKA R., JAROSZ M., 2012. Niedożywienie $i$ zaburzenia odżywiania u kobiet $w$ wieku prokreacyjnym. Post Nauk Med. 25, 965-970

WikAREK T., OlSZANECKA-GLINIANOWICZ M., CHUDEK J., Sikora J., SkatBa P., 2011. Hormon anty-Müllerowski a zaburzenia płodności u otyłych kobiet $i$ kobiet $z$ zespołem policystycznych jajników. Ginekol. Pol. 82, 205-209.

Wilsnack S., Klassen A. D., Wilsnack R. W., 1984. Drinking.and reproductive dysfunction among women in a 1981 national survey. Alcohol Clin. Exp. Res. 8, 451-458

WoŁowIEC D., 2013. Niedobór żelaza:jego następstwa kliniczne $i$ leczenie. Terapia 284, 36-41.

ZAADSTRA B. M., SEIDEll J. C., VAN NOORD P. A., TE Velde E. R., HabBema J. D., VRieswiJk B., KARBAAT J., 1993. Fat and female fecundity: prospective study of effect of body fat distribution on conception rates. BMJ 206, 484-487.

Ziomkiewicz A., Ellison P. T., Lipson S. F., ThUne I., JASIENSKA G., 2008. Body fat, energy balance and estradiol levels: a study based on hormonal profiles from complete menstrual cycles. Hum. Reprod. 23, 2555-2563. 
KOSMOS Vol. 67, 2, 425-439, 2018

\section{Monika Bojanowska, MaŁgorzata Kostecka}

Department of Chemistry, Faculty of Food Science and Biotechnology, University of Life Sciences, 8 Skromna Str., 20-704 Lublin, E-mail: monika.bojanowska@up.lublin.pl

\section{DIET AND LIFESTYLE AS FACTORS INFLUENCING FERTILITY}

\section{Summary}

The fertility disorders are associated not only with the age (aging of the ovaries and testes and the deterioration of the quality of gametes), but also with the negative impact of environmental and occupational factors, as well as lifestyle. The elements of lifestyle include diet, physical activity, smoking and alcohol consumption. The paper discusses the role of individual nutrients such as proteins, carbohydrates, fats, vitamins and minerals in the context of reproductive processes. Improper diet, excess or shortage of body weight are the factors that significantly affect the fertility of both women and men.

Key words: diet, fertility, minerals, physical activity, vitamins 